\title{
Cultural adaptation to Brazilian Portuguese of the Face, Legs, Activity, Cry, Consolability revised (FLACCr) scale of pain assessment
}

\author{
Edna Aparecida Bussotti ${ }^{1}$ \\ Ruth Guinsburg ${ }^{2}$ \\ Mavilde da Luz Gonçalves Pedreira ${ }^{3}$
}

\begin{abstract}
Objective: to perform the translation into Brazilian Portuguese and cultural adaptation of the Face, Legs, Activity, Cry, Consolability revised (FLACCr) scale, with children under 18 years old, affected by cerebral palsy, presenting or not cognitive impairment and unable to report their pain. Method: methodological development study of translation into Portuguese and cultural adaptation of the FLACCr. After approval by the ethics committee, the process aimed at translation and back-translation, evaluation of translation and back-translation using the Delphi technique and assessment of cultural equivalence. The process included the five categories of the scale and the four application instructions, considering levels of agreement equal to or greater than $80 \%$. Results: it was necessary three rounds of the Delphi technique to achieve consensus among experts. The agreement achieved for the five categories was: Face 95.5\%, Legs $90 \%$, Activity $94.4 \%$, Cry $94.4 \%$ and Consolability $99.4 \%$. The four instructions achieved the following consensus levels: 1st 99.1\%, 2nd 99.2\%, 3rd 99.1\% and 4th 98.3\%. Conclusion: the method enabled the translation and cultural adaptation of the FLACCr. This is a study able to expand the knowledge of Brazilian professionals on pain assessment in children with $\mathrm{CP}$

Descriptors: Pain; Child; Cerebral Palsy; Validation Studies.
\end{abstract}

\footnotetext{
1 Doctoral student, Escola Paulista de Enfermagem, Universidade Federal de São Paulo, São Paulo, SP, Brazil.

2 PhD, Full Professor, Escola Paulista de Medicina, Universidade Federal de São Paulo, São Paulo, SP, Brazil.

3 PhD, Associate Professor, Escola Paulista de Enfermagem, Universidade Federal de São Paulo, São Paulo, SP, Brazil.
}

Corresponding Author:

Edna Aparecida Bussotti

Rua Ernesto dos Santos, 247

Jardim Independência

CEP: 03225-000, São Paulo, SP, Brasil

E-mail: edna.bussotti@samaritano.org.br
Copyright () 2015 Revista Latino-Americana de Enfermagem This is an Open Access article distributed under the terms of the Creative Commons Attribution Non-Commercial License (CC BY-NC).

This license lets others distribute, remix, tweak, and build upon your work non-commercially, and although their new works must also acknowledge you and be non-commercial, they don't have to license their derivative works on the same terms. 


\section{Introduction}

Pain assessment in the pediatric population demands technical-scientific knowledge and practical skill. It is a complex process, both for the professionals who provide care, and for researchers ${ }^{(1)}$. The challenge becomes more evident when related to the pain assessment in children with neurological impairment, especially of the cognitive system and speech.

Among the most prevalent pathologies that compromise the neurological system of the child stands out Cerebral Palsy (CP), which affects around 2 to 3:1000 live births in developed countries $^{(2)}$ and anchors the focus of this study.

$\mathrm{CP}$ is defined as a group of disorders of the development of posture and movement, causing restriction of activity, attributed to non-progressive disturbances in the brain during fetal development or infancy. The motor disorders of CP are often accompanied by sensory, cognitive, communication and perception disturbances, occurring or not behavioral disorders and convulsive process $^{(3)}$. In view of this complexity, the use of validated and reliable pain assessment tools is a recommended practice ${ }^{(4-5)}$.

Among the structured tools for pain assessment in children with neurological impairment, stands out the Face, Legs, Activity, Cry, Consolability revised (FLACCr).

The FLACC scale of pain assessment was developed in 1997, based on behavioral parameters, intended for use by health professionals and aiming at contributing to clinical practice in pain assessment in nonverbal children or with speech impairment, which are unable to report their pain ${ }^{(4)}$. Since 2002, the authors of the FLACC scale made modifications in the evaluation descriptors, in order to adapt it to the care of children with cognitive impairment, aged between 4 and 19 years. The authors named it FLACC revised (FLACCr) or revised FLACC (rFLACC $^{(5-7)}$, and changed and expanded to four the number of application instructions of the scale.

The FLACCr presents five evaluation categories, with combined scores ranging from zero to ten. The author classified the scores as follows: zero to three (mild pain); four to six (moderate pain) and seven to ten (severe pain).

Given the paucity of research on systematic pain assessment in children with $\mathrm{CP}$, this study aimed to perform the translation into Brazilian Portuguese and cultural adaptation of the FLACCr scale of pain assessment with children affected by $\mathrm{CP}$, presenting cognitive impairment or not and unable to report their pain.

\section{Method}

This is a methodological development study for translation into Portuguese and cultural adaptation of the FLACCr scale of pain assessment. After formal authorization from the author of the scale, the study was developed in two stages: translation into Brazilian Portuguese and cultural adaptation of the FLACCr scale of pain assessment. The study was submitted to the Ethics Committee of the Federal University of São Paulo, and approved under protocol number 1480/10.

The criteria for translation and cultural adaptation of the FLACCr scale into Portuguese followed a specific model, considering three stages: translation and back-translation, evaluation of translation and backtranslation and cultural equivalence( ${ }^{(8)}$.

\section{Translation into Portuguese and back-translation into English}

Translation and back-translation were performed by two independent certified translators, not belonging to the healthcare area, with fluency in both languages, inclusive in their colloquial forms.

\section{Evaluation of translation and back-translation by an expert committee}

Five experts were invited, according to the following inclusion criteria: fluency in English; availability to participate in the project by the final consensus on the instrument; master's degree as minimum postgraduate level, on the theme "Pain in the pediatric/neonatal population"; practice in clinical pediatric for over a year; experience in assisting child with $\mathrm{CP}$ (with or without comorbidities) and other neurological disorders (periods stratified in the questionnaire); and formal acceptance of their participation by signing the Free Informed Consent Form.

The method used to achieve consensus was the Delphi technique, which ensures anonymity of the experts, with absolute confidentiality of the responses. The evaluation was performed based on the set of these experts' responses. The method allowed to achieve consensus among a group of experts on a phenomenon of a certain area of knowledge(9).

To carry out the evaluation of the FLACCr, it was used the Likert scale, which is based on the indication of a degree of agreement or disagreement of the translation and back translation, comparing them with 
the original scale. In this process, it was included the five evaluation categories/indicators and the four scale application instructions. For each item evaluated the following classification was used: Strongly Disagree (SD); Disagree (D); Neither Agree Nor Disagree (NAND); Agree (A); Strongly Agree (SA).

It was asked to the experts to assess the semantic equivalence, idiomatic equivalence and experimental or cultural equivalence ${ }^{(8)}$. This evaluation also aimed to verify the validation of the content of the scale.

\section{Cultural equivalence}

This phase aimed to analyze the equivalence between the original and final versions of the scale. It was opted for the investigative technique, which recommends a sample of participants, preferably between 30 and 40, to evaluate the final version of the scale $^{(10)}$. Accordingly, 38 professionals were invited (18 nurses, 10 physicians and 10 physiotherapists), and 30 (78.9\%) returned the completed questionnaires.

These professionals evaluated the title, the five categories of pain assessment proposed in the FLACCr scale, with their respective descriptors and the four scale's application instructions, according to the following attributes ${ }^{(11)}$ : Comprehensibility - the category evaluated expressed clarity and intelligibility; Simplicity - the category evaluated expressed one idea; Objectivity - the assessed category allows one response, considering the behaviors described; Typicity - the evaluated category is expressed in a consistent or typical way proper of the assessed category; Relevance - the category evaluated expresses relevance with consistent phrases; Credibility - the evaluated category is described in a way that does not seem uncharacteristic or unreasonable.

The evaluation of each attribute was performed by means of the Likert scale, with the classifications SD, D, NAND, A and SA.

Some researchers consider that the minimum consensus levels are between $50 \%$ and $80 \%^{(12-}$ 13). Therefore, it was selected the minimum level of agreement of $80 \%$, both for the five experts, in the consensus phase of the translation and cultural equivalence, as for the 30 professionals who participated in the cultural adaptation phase.

The results were analyzed using descriptive statistics, measurements of absolute and relative frequencies of the responses emitted by the committee of five experts and by the 30 health professionals, considering levels of agreement equal to or greater than
$80 \%$. The results were obtained by the sum of the values of the classification items SA and A of the Likert scale.

The final version of the instrument back-translated into English was sent to the author of the original scale, and had full agreement with the Brazilian version.

\section{Results}

The participants of the experts committee were a physician and four nurses, respecting all the inclusion criteria previously established. The translated and backtranslated versions of the scale were sent to the experts for consensus, thus constituting the first round of evaluation.

In the results of the expert committee, it was observed that the instrument had not achieved consensus equal to or greater than $80 \%$ in the translation and backtranslation of the categories: Face ( $60 \%$ consensus in translation and $40 \%$ in back-translation), Activity (40\% consensus in translation and $50 \%$ in back-translation), Cry $(60 \%$ consensus in translation and $50 \%$ in backtranslation), Consolability (60\% consensus in translation and $60 \%$ in back- translation), $1^{\text {st }}$ scale application instruction $(60 \%$ consensus in translation and $60 \%$ in back-translation), $2^{\text {nd }}$ instruction ( $40 \%$ consensus in translation), $3^{\text {rd }}$ instruction (60\% consensus in translation and $60 \%$ in back-translation) and $4^{\text {th }}$ instruction (20\% consensus in translation and $20 \%$ in back-translation).

The description of the Activity category, in the score 1 , was sent to the author of the original scale, to clarify the term splinting, as suggested by one of the experts. The author explained that this word is related to the respiratory condition of the child, contributing to the consensus of the committee. The word gasping was maintained in English, because there is no translation into Portuguese and it is often used in clinical practice.

The suggestions of the committee were adopted, continuing the second round of evaluation by the experts.

By receiving the versions of the second round, it was identified a lack of consensus for the $4^{\text {th }}$ scale application instruction. The researchers considered the suggestions of the experts, requiring a third round. After the versions of the committee has returned, it was identified agreement equal to or greater than $80 \%$ in all categories of the scale.

The author of the original scale asked to maintain the title as it stands in English (FLACCr), with possible insertion of the letter " $r$ " at the beginning or end of the title. Consequently, the symbol FLACCr was maintained in the Portuguese version spoken in Brazil, as shown in Figure 1. 


\begin{tabular}{|c|c|c|c|}
\hline \multirow{2}{*}{ Categorias } & \multicolumn{3}{|c|}{ Pontuação } \\
\hline & 0 & 1 & 2 \\
\hline $\begin{array}{l}\text { F } \\
\text { Face }\end{array}$ & $\begin{array}{l}\text { Sem expressão } \\
\text { particular ou sorriso }\end{array}$ & $\begin{array}{l}\text { Presença ocasional de careta ou sobrancelhas } \\
\text { salientes, introspecção, desinteresse. } \\
\text { Parece triste ou preocupado }\end{array}$ & $\begin{array}{l}\text { Sobrancelhas esporadicamente ou } \\
\text { constantemente salientes, mandíbulas } \\
\text { cerradas, queixo trêmulo. } \\
\text { Face aparentando estresse: expressão } \\
\text { assustada ou de pânico }\end{array}$ \\
\hline $\begin{array}{l}\text { P } \\
\text { Pernas }\end{array}$ & $\begin{array}{l}\text { Posição normal ou } \\
\text { relaxada }\end{array}$ & $\begin{array}{l}\text { Desconforto, inquietação, tensão. Tremores } \\
\text { ocasionais }\end{array}$ & $\begin{array}{l}\text { Chutes ou pernas soltas. } \\
\text { Aumento considerável da espasticidade, } \\
\text { tremores constantes ou sacudidelas }\end{array}$ \\
\hline $\begin{array}{l}\text { A } \\
\text { Atividade }\end{array}$ & \begin{tabular}{|l|} 
Em silêncio, \\
posição normal, \\
movimentando-se \\
facilmente
\end{tabular} & $\begin{array}{l}\text { Contorcendo-se, movimentando o corpo para } \\
\text { frente e para trás, tensão. } \\
\text { Moderadamente agitado (por exemplo, } \\
\text { movimento da cabeça para a frente e para trás, } \\
\text { comportamento agressivo); respiração rápida, } \\
\text { superficial, suspiros intermitentes }\end{array}$ & $\begin{array}{l}\text { Corpo arqueado, rígido ou trêmulo. } \\
\text { Agitação intensa, cabeça chacoalhando (não } \\
\text { vigorosamente), tremores, respiração presa em } \\
\text { gasping ou inspiração profunda, intensificação } \\
\text { da respiração rápida e superficial }\end{array}$ \\
\hline $\begin{array}{l}\text { C } \\
\text { Choro }\end{array}$ & $\begin{array}{l}\text { Sem choro (acordado } \\
\text { ou dormindo) }\end{array}$ & $\begin{array}{l}\text { Gemidos ou lamúrias, reclamações ocasionais. } \\
\text { Impulsos verbais ou grunhidos ocasionais }\end{array}$ & $\begin{array}{l}\text { Choro regular, gritos ou soluços, reclamações } \\
\text { frequentes. } \\
\text { Repetidos impulsos verbais, grunhidos } \\
\text { constantes }\end{array}$ \\
\hline $\begin{array}{l}\text { C } \\
\text { Consolabilidade }\end{array}$ & Contente, relaxado & $\begin{array}{l}\text { Tranquilizado por toques ocasionais, abraços } \\
\text { ou conversa e distração }\end{array}$ & $\begin{array}{l}\text { Difícil de consolar ou confortar. } \\
\text { Rejeita o cuidador, resiste ao cuidado ou a } \\
\text { medidas de conforto }\end{array}$ \\
\hline \multicolumn{4}{|c|}{ Orientações para aplicação da escala } \\
\hline \multicolumn{4}{|c|}{$\begin{array}{l}\text { 1- Cada uma das cinco categorias (F) Face; (L) Pernas; (A) Atividade; (C) Choro; (C) Consolabilidade é pontuada de 0-2, resultando num escore total } \\
\text { entre zero e dez. } \\
\text { 2- Pacientes acordados: Observe por pelo menos 1-2 minutos. Observe pernas e corpo descobertos. Reposicione o paciente ou observe a atividade, } \\
\text { avalie tonicidade e tensão corporal. Inicie intervenções de consolo, se necessário. } \\
\text { 3- Pacientes dormindo: Observe por pelo menos } 2 \text { minutos ou mais. Observe corpo e pernas descobertos. Se possível, reposicione o paciente. } \\
\text { Toque o corpo e avalie tonicidade e tensão. } \\
\text { 4- A FLACC revisada pode ser utilizada para todas as crianças não verbais. } \\
\text { As descrições adicionais (em negrito) são descritores validados em crianças com dificuldades cognitivas. A enfermeira pode revisar com os pais os } \\
\text { descritores dentro de cada categoria. } \\
\text { Pergunte a eles se há comportamentos adicionais que melhor indiquem a dor em seus filhos. } \\
\text { Adicione esses comportamentos na categoria apropriada da escala. }\end{array}$} \\
\hline \multicolumn{4}{|c|}{$\begin{array}{c}\text { C 2002, The Regents of the University of Michigan. All Rights Reserved 09-09-2009 } \\
\text { Bussotti EA, Guinsburg R, Pedreira MLG. Traduzido para a língua portuguesa. } \\
\text { Brasil - São Paulo, junho de 2013. }\end{array}$} \\
\hline
\end{tabular}

Figure 1 - Final version in Portuguese spoken in Brazil of the FLACCr scale of pain assessment. São Paulo, SP, Brazil, 2013

In the cultural equivalence phase, of the 30 participating professionals, 18 were nurses, six physicians and six physiotherapists. Of the total, 28 (93.3\%) were female and $26(86.6 \%)$ had professional training time and time of performance in pediatrics greater than 10 years. When they were asked about the approximate frequency of assistance to children with $\mathrm{CP}$ in the last year, 11 (36.6\%) responded that daily took care of children with $\mathrm{CP}, 11$ (36.6\%) took care often (more than once a month), seven (23.6\%) took care few times (once every two months) and one (3.2\%) rarely took care (once every three months).

The professionals evaluated the five categories of the Face, Legs, Activity, Cry and Consolability scale, considering the attributes Comprehensibility, Simplicity and Objectivity, as shown in Table 1, and Typicity, Relevance and Credibility, as shown in Table 2.

The five categories of the scale, shown in Tables 1 and 2 , achieved consensus greater than $80 \%$, ranging as follows: Face from $93 \%$ to $100 \%$ (95.5\% average); Legs from $83.3 \%$ to $93.3 \%$ ( $90 \%$ average); Activity from $90 \%$ to $100 \%$ ( $94.4 \%$ average); Cry from $90 \%$ to $96.6 \%$ (94.4 average); and Consolability from $96.7 \%$ to $100 \%$ (99.4\% average). Although the Legs category had achieved consensus with satisfactory results, it presented the lowest average of agreement when compared to the other categories. The 30 professionals also evaluated the four instructions for the application of the scale, according to the attributes Comprehensibility, Simplicity, Relevance and Credibility, as shown in Table 3.

The four scale instructions achieved consensus greater than $80 \%$, ranging as follows: $1^{\text {st }}$ instruction from $96.7 \%$ to $100 \%$ ( $99.1 \%$ average); $2^{\text {nd }}$ instruction from $96.7 \%$ to $99.2 \%$ (99.2\% average); $3^{\text {rd }}$ instruction from $96.7 \%$ to $100 \%(99.1 \%$ average $) ;$ and $4^{\text {th }}$ instruction from $96.6 \%$ to $100 \%$ ( $98.3 \%$ average). The four instructions presented excellent agreement rates, with the lowest average in the $4^{\text {th }}$ instruction. 
Table 1 - Evaluation of the attributes Comprehensibility, Simplicity and Objectivity, of the five categories of the FLACCr. São Paulo, SP, Brazil, 2013

\begin{tabular}{|c|c|c|c|c|c|c|c|c|c|c|}
\hline \multirow{2}{*}{ Attributes } & \multicolumn{2}{|c|}{ 1-Face } & \multicolumn{2}{|c|}{ 2-Legs } & \multicolumn{2}{|c|}{ 3-Activity } & \multicolumn{2}{|c|}{ 4-Cry } & \multicolumn{2}{|c|}{ 5-Consolability } \\
\hline & $n$ & $\%$ & $n$ & $\%$ & $n$ & $\%$ & $n$ & $\%$ & $\mathrm{n}$ & $\%$ \\
\hline \multicolumn{11}{|l|}{ Comprehensibility } \\
\hline Strongly Disagree & 0 & - & 0 & - & 0 & - & 0 & - & 0 & - \\
\hline Disagree & 2 & 6.6 & 2 & 6.7 & 1 & 3.3 & 2 & 6.7 & 1 & 3.3 \\
\hline Neither Agree Nor Disagree & 0 & - & 2 & 6.7 & 0 & - & 0 & - & 0 & - \\
\hline Agree & 14 & 46.7 & 12 & 40.0 & 17 & 56.7 & 10 & 33.3 & 9 & 30.0 \\
\hline Strongly Agree & 14 & 46.7 & 14 & 46.6 & 12 & 40.0 & 17 & 56.7 & 20 & 66.7 \\
\hline No Answer & 0 & - & 0 & - & 0 & - & 1 & 3.3 & 0 & - \\
\hline Total & 30 & 100.0 & 30 & 100.0 & 30 & 100.0 & 30 & 100.0 & 30 & 100.0 \\
\hline \multicolumn{11}{|l|}{ Simplicity } \\
\hline Strongly Disagree & 0 & - & 0 & - & 0 & - & 0 & - & 0 & - \\
\hline Disagree & 0 & - & 1 & 3.3 & 2 & 6.7 & 0 & - & 0 & - \\
\hline Neither Agree Nor Disagree & 0 & - & 1 & 3.3 & 0 & - & 0 & - & 0 & - \\
\hline Agree & 18 & 60.0 & 13 & 43.4 & 16 & 53.3 & 10 & 33.3 & 8 & 26.7 \\
\hline Strongly Agree & 12 & 40.0 & 15 & 50.0 & 12 & 40.0 & 19 & 63.4 & 22 & 73.3 \\
\hline No Answer & 0 & - & 0 & - & 0 & - & 1 & 3.3 & 0 & - \\
\hline Total & 30 & 100 & 30 & 100 & 30 & 100 & 30 & 100 & 30 & 100 \\
\hline \multicolumn{11}{|l|}{ Objectivity } \\
\hline Strongly Disagree & 0 & - & 1 & 3.3 & 0 & - & 0 & - & 0 & - \\
\hline Disagree & 2 & 6.6 & 0 & - & 3 & 10.0 & 0 & - & 0 & - \\
\hline Neither Agree Nor Disagree & 0 & - & 1 & 3.3 & 0 & - & 0 & - & 0 & - \\
\hline Agree & 14 & 46.7 & 14 & 46.7 & 17 & 56.7 & 10 & 33.3 & 7 & 23.3 \\
\hline Strongly Agree & 14 & 46.7 & 14 & 46.7 & 10 & 33.3 & 19 & 63.4 & 23 & 76.7 \\
\hline No Answer & 0 & - & 0 & - & 0 & - & 1 & 3.3 & 0 & - \\
\hline Total & 30 & 100 & 30 & 100 & 30 & 100 & 30 & 100 & 30 & 100 \\
\hline
\end{tabular}

Table 2 - Evaluation of the attributes Typicity, Relevance and Credibility, of the five categories of the FLACCr. São Paulo, SP, Brazil, 2013

\begin{tabular}{|c|c|c|c|c|c|c|c|c|c|c|}
\hline \multirow{2}{*}{ Attributes } & \multicolumn{2}{|c|}{ 1-Face } & \multicolumn{2}{|c|}{ 2-Legs } & \multicolumn{2}{|c|}{ 3-Activity } & \multicolumn{2}{|c|}{ 4-Cry } & \multicolumn{2}{|c|}{ 5-Consolability } \\
\hline & $\mathbf{n}$ & $\%$ & $\mathbf{n}$ & $\%$ & $\mathbf{n}$ & $\%$ & $\mathbf{n}$ & $\%$ & $\mathbf{n}$ & $\%$ \\
\hline \multicolumn{11}{|l|}{ Typicity } \\
\hline Strongly Disagree & 0 & - & 1 & 3.3 & 1 & 3.3 & 0 & - & 0 & - \\
\hline Disagree & 2 & 6.7 & 0 & - & 0 & - & 1 & 3.3 & 0 & - \\
\hline Neither Agree Nor Disagree & 0 & 0.0 & 4 & 13.3 & 2 & 6.7 & 0 & - & 0 & - \\
\hline Agree & 18 & 60.0 & 13 & 43.4 & 18 & 60.0 & 13 & 43.4 & 10 & 33.3 \\
\hline Strongly Agree & 10 & 33.3 & 12 & 40.0 & 9 & 30.0 & 15 & 50.0 & 20 & 66.7 \\
\hline No Answer & 0 & - & 0 & - & 0 & - & 1 & 3.3 & 0 & - \\
\hline Total & 30 & 100 & 30 & 100 & 30 & 100 & 30 & 100 & 30 & 100 \\
\hline \multicolumn{11}{|l|}{ Relevance } \\
\hline Strongly Disagree & 0 & - & 0 & - & 0 & - & 0 & - & 0 & - \\
\hline Disagree & 1 & 3.3 & 0 & - & 0 & - & 0 & - & 0 & - \\
\hline Neither Agree Nor Disagree & 1 & 3.3 & 5 & 16.7 & 0 & - & 0 & - & 0 & - \\
\hline Agree & 18 & 60.1 & 11 & 36.7 & 21 & 70.0 & 12 & 40.0 & 10 & 33.3 \\
\hline Strongly Agree & 10 & 33.3 & 14 & 46.6 & 9 & 30.0 & 17 & 56.7 & 20 & 66.7 \\
\hline No Answer & 0 & - & 0 & - & 0 & - & 1 & 3.3 & 0 & - \\
\hline Total & 30 & 100 & 30 & 100 & 30 & 100 & 30 & 100 & 30 & 100 \\
\hline \multicolumn{11}{|l|}{ Credibility } \\
\hline Strongly Disagree & 0 & - & 0 & - & 0 & - & 0 & - & 0 & - \\
\hline Disagree & 0 & - & 1 & 3.3 & 1 & 3.3 & 0 & - & 0 & - \\
\hline Neither Agree Nor Disagree & 0 & - & 2 & 6.7 & 0 & - & 0 & - & 0 & - \\
\hline Agree & 20 & 66.7 & 12 & 40.0 & 18 & 60.0 & 12 & 40.0 & 10 & 33.3 \\
\hline Strongly Agree & 10 & 33.3 & 15 & 50.0 & 11 & 36.7 & 17 & 56.7 & 20 & 66.7 \\
\hline No Answer & 0 & - & 0 & - & 0 & - & 1 & 3.3 & 0 & - \\
\hline Total & 30 & 100 & 30 & 100 & 30 & 100 & 30 & 100 & 30 & 100 \\
\hline
\end{tabular}


Table 3 - Evaluation of the attributes Comprehensibility, Simplicity, Relevance and Credibility, of the four instructions of the FLACCr. São Paulo, SP, Brazil, 2013

\begin{tabular}{|c|c|c|c|c|c|c|c|c|}
\hline \multirow{2}{*}{ Attributes } & \multicolumn{2}{|c|}{$1^{\text {st }}$ Instruction } & \multicolumn{2}{|c|}{$2^{\text {nd }}$ Instruction } & \multicolumn{2}{|c|}{$3^{\text {rd }}$ Instruction } & \multicolumn{2}{|c|}{$4^{\text {th }}$ Instruction } \\
\hline & $\mathrm{n}$ & $\%$ & $\mathbf{n}$ & $\%$ & $n$ & $\%$ & $\mathrm{n}$ & $\%$ \\
\hline \multicolumn{9}{|l|}{ Comprehensibility } \\
\hline Strongly Disagree & 0 & - & 0 & - & 0 & - & 0 & - \\
\hline Disagree & 0 & - & 0 & - & 0 & - & 1 & 3.3 \\
\hline Neither Agree Nor Disagree & 0 & - & 0 & - & 0 & - & 0 & - \\
\hline Agree & 12 & 40.0 & 13 & 43.3 & 15 & 50.0 & 13 & 43.3 \\
\hline Strongly Agree & 18 & 60.0 & 17 & 56.7 & 15 & 50.0 & 16 & 53.4 \\
\hline No Answer & 0 & - & 0 & - & 0 & - & 0 & - \\
\hline Total & 30 & 100 & 30 & 100 & 30 & 100 & 30 & 100 \\
\hline \multicolumn{9}{|l|}{ Simplicity } \\
\hline Strongly Disagree & 0 & - & 0 & - & 0 & - & 0 & - \\
\hline Disagree & 1 & 3.3 & 0 & - & 0 & - & 1 & 3.3 \\
\hline Neither Agree Nor Disagree & 0 & - & 0 & - & 1 & 3.3 & 0 & - \\
\hline Agree & 11 & 36.7 & 14 & 46.7 & 14 & 46.7 & 13 & 43.3 \\
\hline Strongly Agree & 18 & 60.0 & 16 & 53.3 & 15 & 50.0 & 16 & 53.4 \\
\hline No Answer & 0 & - & 0 & - & 0 & - & 0 & - \\
\hline Total & 30 & 100 & 30 & 100 & 30 & 100 & 30 & 100 \\
\hline \multicolumn{9}{|l|}{ Relevance } \\
\hline Strongly Disagree & 0 & - & 0 & - & 0 & - & 0 & - \\
\hline Disagree & 0 & - & 0 & - & 0 & - & 0 & - \\
\hline Neither Agree Nor Disagree & 0 & - & 0 & - & 1 & 3.3 & 0 & - \\
\hline Agree & 12 & 40.0 & 13 & 43.3 & 13 & 43.3 & 11 & 36.7 \\
\hline Strongly Agree & 18 & 60.0 & 17 & 56.7 & 16 & 53.4 & 19 & 63.3 \\
\hline No Answer & 0 & - & 0 & - & 0 & - & 0 & - \\
\hline Total & 30 & 100 & 30 & 100 & 30 & 100 & 30 & 100 \\
\hline \multicolumn{9}{|l|}{ Credibility } \\
\hline Strongly Disagree & 0 & - & 0 & - & 0 & - & 0 & - \\
\hline Disagree & 0 & - & 0 & - & 0 & - & 0 & - \\
\hline Neither Agree Nor Disagree & 0 & - & 0 & - & 0 & - & 0 & - \\
\hline Agree & 12 & 40.0 & 12 & 40.0 & 15 & 50.0 & 12 & 40.0 \\
\hline Strongly Agree & 18 & 60.0 & 18 & 60.0 & 15 & 50.0 & 18 & 60.0 \\
\hline No Answer & 0 & - & 0 & - & 0 & - & 0 & - \\
\hline Total & 30 & 100 & 30 & 100 & 30 & 100 & 30 & 100 \\
\hline
\end{tabular}

\section{Discussion}

The selection of the scale to be translated and submitted to cultural adaptation was determined after various researches in the literature, involving discussions with professionals on feasible instruments to be applied at the bedside and previous experience of the researchers in using the FLACC. Some authors describe the FLACCr as a tool of easy application at the bedside and discuss the accuracy and sensitivity of other instruments for use in children with neurological impairment. The purpose is to assist in the best possible way, this population so vulnerable ${ }^{(14-15)}$.
Is worth mentioning that, in 2011, the Royal College of Nursing(16) published a guide of good clinical practices for recognition and evaluation of acute pain in children, which included the evaluation of children with neurological impairment. Among the existing instruments, the FLACCr was indicated as an appropriate tool for this population. It was emphasized the importance of the fourth scale instruction, in which family/caregiver are asked about specific behaviors considered warning signs for the characterization of pain. The guide also emphasized that instruments must contain well-established validity and reliability. 
This study provides a specific method. Researchers in this area recommend two translators for validation and two translators for back-translation(8). In 2003, it was proposed to simplify the methodology, specifically in the stages of translation and back-translation(17). In this sense, some authors have simplified the stages of translation and back-translation without compromising the quality of the final version ${ }^{(18-19)}$.

This study followed the method described in the literature ${ }^{(8)}$, with variation in the number of translators in the stages of translation and back-translation, which did not influence in the results presented in Tables 1 , 2 and 3. As consensus, it was considered agreement indexes greater than or equal to $80 \%$.

The 30 professionals (experts) who participated in the assessment of cultural equivalence of the FLACCr were from different categories (multidisciplinary), according to the theoretical reference used $(8,10)$. The group was comprised by professionals with experience in pediatrics and assistance for children with $\mathrm{CP}$, evidencing that 26 $(86.6 \%)$ had experience in the area of pediatrics for over 10 years and $73.2 \%$ had assisted children with CP daily and frequently in the previous year. It is possible to state that, the results obtained in the cultural equivalence phase, in which the adjustment has been completed, are consistent with evidence of satisfactory results.

By evaluating the consensus results, as shown in Tables 1 and 2, it is observed that the Legs category achieved the lowest level of agreement among experts, ranging from $83.3 \%$ to $93.3 \%$ and average of $90 \%$ in the attributes evaluated, when compared to other categories, especially in the attributes Comprehensibility, Typicity and Relevance.

Children with CP may present significant variations related to postural impairment and movement of the limbs. According to the proposal, using the scale of pain assessment, the evaluator should talk to family/ caregiver on behavior and conducts considered normal for the child and warning signs of pain, representing a complementary procedure for an accurate evaluation. In the absence of family/caregiver, the professional is committed to observe the child more frequently, recognizing behaviors and normal postures and warning signs $^{(20)}$. It was also investigated the definition of the word "Normal" in a Portuguese dictionary ${ }^{(21)}$ : it refers to what is common or usual. Thus, the descriptors of the Legs category were maintained according to established consensus.

The $4^{\text {th }}$ scale instruction had the lowest level of agreement among experts, in the first round. The discussion among the experts was related to the comprehension of the first sentence of the orientation: "The revised FLACC can be used for all non-verbal children". Some experts asked whether the scale could be used only for non-verbal children. At the end of the $3^{\text {rd }}$ round, it was achieved consensus among the experts on the applicability of the FLACCr for all non-verbal children and the descriptors added in bold apply to children with cognitive impairment. In other words, the author has maintained the original FLACC scale, appropriate for all non-verbal children (without neurological impairment) and added descriptors for children with neurological impairment on the same scale, resulting in the FLACCr.

The $4^{\text {th }}$ orientation has achieved excellent levels of agreement among experts, ranging from $96.6 \%$ to $100 \%$ and average of $98.3 \%$, regarding pain assessment in non-verbal children. However, the $4^{\text {th }}$ instruction is clear and highlights that the practitioner can approach the family/caregiver to discuss specific behaviors indicative of pain, which can be added to the scale, so that other professionals have access to this information. Researchers on the theme reinforce the importance of family approach/caregivers of children with $\mathrm{CP}$, helping in the recognition of signals of pain and thus contributing to a better clinical outcome $e^{(20,22)}$.

The other categories of the scale achieved consensus greater than $80 \%$, with some considerations on the approximation of the professional at the bedside, in the approach of family/caregiver.

Is worth mentioning that, it is still incipient the discussions on pain assessment in vulnerable populations, such as children with CP. The difficulties are broad and the lack of professionals qualified and interested in the theme generates inefficiency in clinical practice. Some studies reveal that individuals with cognitive impairment are particularly vulnerable to undertreatment of pain when compared to those without cognitive impairment and able to report their pain. Moreover, some researchers have described the lack of standards of pain assessment for this population as vulnerable ${ }^{(5-6)}$. Consequently, it is urgent in this environment, the instrumentalization of health professionals with tools able to standardize the practices and generate clinical and administrative indicators. Validated instruments of pain assessment are useful tools when used in a planned and systematic manner, particularly in the development of the discussion within the care team on forms of assessment and management of pain, enabling continuous process improvement $^{(14)}$. 


\section{Conclusion}

By following the methodological instructions, it was possible to develop, with satisfactory results, the translation and adaptation of the FLACCr scale of pain assessment.

The selection of the participating professionals of this first stage was essential to achieve the stated results.

The use of scales of pain assessment is a reality in some institutions. It is recommended the provision of properly validated scales. If the healthcare team chooses an existing instrument in another language, it is necessary to develop the process of translation and cultural adaptation. Therefore, it will be possible to assess pain more reliably.

The next stage of this study is to evaluate the reliability and consistency of the psychometric properties of the FLACCr in children with CP.

This is one of the pioneering works in Brazil focused on the pediatric population with $\mathrm{CP}$, presenting or not cognitive impairment. In addition, the study requires continuity, so that this population is favored with adequate pain management.

\section{References}

1. Mitchell A, Boss BJ. Adverse effects of pain on the nervous systems of newborns and young children: a review of literature. J Neurosci Nurs. 2002 Oct;34(5):228-36.

2. Power R, Mcmanus V, Fourie R. Hardship, dedication and investment: An exploration of Irish mothers commitment to communicating with their children with cerebral palsy. J Psychiatr Ment Health Nurs. 2009Aug;16(6):531-8.

3. Bax M, Goldstein M, Rosenbaum $P$, Leviton $A$, Paneth N, Dan B, et al. Proposed definition and classification of cerebral palsy. Dev Med Child Neurol. 2005Aug;47(8):571-6.

4. Merkel SI, Voepel-Lewis T, Shayevitz JR, Malviya S.The FLACC: a behavioral scale for scoring postoperative pain in young children. Pediatric Nursing. 1997 MayJun;23(3):293-7.

5. Voepel-Lewis T, Merkel S, Tait AR, Trzcinka A, Malviya

S. The reliability and validity of the Face, Leg, Activity,

Cry, Consolability Observational Tool as a measure of pain in children with cognitive impairment. Anesth Analg. 2002 Nov;95(5):1224-9.

6. Malviya S, Voepel-Lewis T, Burke CN, Merkel S, Tait AR. The revised FLACC observational pain tool: improved reliability and validity for pain assessment in children with cognitive impairment. Pediatr Anesthesia. 2006 Mar;16(3):258-65.

7. Manworren RC, Hynan LS. Clinical validation of FLACC: preverbal patient pain scale. Pediatr Nurs. 2003MarApr;29(2):140-6.

8. Guillemin F, Bombardier C, Beaton DE. Cross-cultural adaptation of health-related quality of life measures: literature review and proposed guidelines. J Clin Epidemiol. 1993;46(12): 1414-32.

9. Faro ACM. Técnica Delphi na validação das intervenções de enfermagem. Rev. Esc. Enf.USP. 1997 ago;31(1):259-73.

10. Beaton DE, Bombardier C, Guillemin F, Ferraz MB. Guidelines for the process of cross-cultural adaptation of self-report measures. Spine. 2000;25(24):3186-91.

11. Pasquali L. Psicometria. Rev Esc Enferm USP. 2009;43(Esp): 992-9.

12. Salmond SW. Orthopedic nursing research priorities: a Delphi study. Orthop Nurs. 1994 Mar-Apr;13(2):31-45. 13. Grant JS, Kinney MR. Using the Delphi tecnique to examine the content validity of nursing diagnosis. Nurs Diagn. 1992 Jan-Mar;3(1):12-22.

14. Bussotti EA, Pedreira MLG. Pain in children with cerebral palsy and implications on nursing practice and research: integrative review. Rev Dor. (São Paulo) 2013;14(2):142-6.

15. Hunt AK, Franck LS. Special needs require special attention: A pilot project implementing the paediatric pain profile for children with profound neurologic impairment in a in-patient following surgery. J Child Health Care. 2011 Sep;15(3):210-20.

16. Royal College of Nursing. Clinical Practice Guideline: The recognition and assessment of acute pain in children. [Internet]. 2009 [acesso 20 jun 2013]. Disponível em: http://www.rcn.org.uk/_data/assets/ pdf_file/0004/269185/003542.pdf

17. Falcão DM, Ciconelli RM, Ferraz MB. Translation and Cultural Adaptation of Quality of Life Questionnaires: An Evaluation of Methodology. J Rheumatol. 2003 Feb;30(2):379-85.

18. Salvetti MG, Pimenta CAM. Validação da Chronic Pain Self-Efficacy Scale para a Língua Portuguesa. Rev Psiq Clín. 2005;32(4):202-10.

19. Ayres MT. Adaptação Transcultural para o Português do Instrumento "The Bowel Disease Questionnaire", utilizado para a avaliação de desordens gastrointestinais funcionais. Rio de Janeiro [dissertação] Núcleo de Estudos de Saúde Coletiva do Departamento de Medicina Preventiva. Universidade Federal do Rio de Janeiro 
[Internet]. 2003 [acesso 20 out 2013]. Disponível em: http://www.posgraduacao.iesc.ufrj.br/media/ tese/1372778284.pdf

20. Solodiuk J, Curley MAQ. Pain Assessment in nonverbal Children with severe congnitive impairment: The Individualized Numeric Rating Scale. J Pediatric Nurs. (INRS). 2003 Aug;18(4):295-9.

21. Ferreira $A B H$. Mini Aurélio: dicionário da língua portuguesa. [Internet]. 2008. [acesso $10 \mathrm{dez} 2014$ ]. Disponível em: http://www.agaleradodownload.org/ novo-dicionario-aurelio-5-0

22. Hunt A, Goldman A, Seers K, Crichton N, Mastroyannopoulou K, Moffat $\mathrm{V}$, et al. Clinical validation of the paediatric pain profile. Dev Med Child Neurol. 2004 Jan;46(1):9-18. 